\title{
Upaya Meningkatkan Aktivitas Belajar Siswa dalam Pembelajaran IPA Melalui Model Pembelajaran Kooperatif Tipe Jigsaw di SMP Negeri 7 Bukittinggi Provinsi Sumatra Barat
}

\author{
Nilawati \\ SMPN 2 Bukittinggi, Kota Bukittinggi - Provinsi Sumatera Barat \\ Corresponding Author. Email: nilawati798@gmail.com
}

\begin{abstract}
This study aims to increase student learning activities in science learning through the Jigsaw type learning model at SMPN 7 Bukittinggi. This research method used classroom action research which is carried out in 2 cycles. The instrument used is an observation sheet. The data analysis technique of this research used quantitative and qualitative descriptive analysis. The results of this study indicate that based on the results of the first cycle of student activity in bringing source books/reading 50.3\%, cooperation in groups 59.6\%, expressing opinions in large groups $35.7 \%$, working on questions in groups $45.7 \%$, pointing to hands answered the quiz $24 \%$. While in the second cycle there was a significant increase, in the aspect of bringing source books/reading $67.5 \%$, cooperation in groups $74 \%$, expressing opinions in large groups $59 \%$, working on questions in groups $76 \%$, and pointing hands to answer quizzes $65 \%$ . This shows that the learning activities of grade VII-8 students of SMPN 7 Bukitinggi are in the high category. So it can be concluded that the Jigsaw type learning model can improve student learning activities in science learning.
\end{abstract}

\author{
Article History \\ Received: 11-05-2021 \\ Revised: 08-06-2021 \\ Accepted: 11-06-2021 \\ Published: 07-07-2021
}

\section{Key Words:}

Learning Activities, Cooperative Learning, Jigsaw.

\begin{abstract}
Abstrak: Penelitian ini bertujuan untuk meningkatkan aktivitas belajar siswa Sejarah Artikel dalam pembelajaran IPA melalui model pembelajaran tipe Jigsaw di SMPN 7 Diterima: 11-05-2021 Bukittinggi. Metode penelitian ini menggunakan penelitian tindakan kelas yang Direvisi: 08-06-2021 dilaksanakan dalam 2 siklus. Istrumen yang digunakan adalah lembar observasi. Disetujui: 11-06-2021 Teknik analisis data penelitian ini menggunakan analisis deskriptif kuantitatif dan Diterbitkan: 07-07-2021 kualitatif. Hasil penelitian ini menunjukkan bahwa berdasarkan hasil siklus pertama aktivitas siswa dalam membawa buku sumber/bacaan 50,3\%, kerjasama dalam kelompok 59,6\%, mengeluarkan pendapat pada kelompok besar $35,7 \%$, mengerjakan soal dalam kelompok 45,7\%, menunjuk tangan menjawab kuiz 24\%. Kata Kunci: Sedangkan pada siklus kedua mengalami peningkatan yang cukup segnifikan, Aktivitas Belajar, dalam aspek membawa buku sumber/bacaan 67,5\%, kerjasama dalam kelompok Pembelajaran Kooperatif, $74 \%$, mengeluarkan pendapat pada kelompok besar 59\%, mengerjakan soal dalam Jigsaw.

kelompok $76 \%$, dan menunjuk tangan menjawab kuiz $65 \%$. Hal ini menunjukkan aktivitas belajar siswa kelas VII-8 SMPN 7 Bukitinggi berada dalam kategori tinggi. Sehingga dapat disimpulkan bahwa model pembelajaran tipe Jigsaw dapat meningkatkan aktivitas belajar siswa dalam pembelajaran IPA.
\end{abstract}

How to Cite: Nilawati, N. (2021). Upaya Meningkatkan Aktivitas Belajar Siswa dalam Pembelajaran IPA Melalui Model Pembelajaran Kooperatif Tipe Jigsaw di SMP Negeri 7 Bukittinggi Provinsi Sumatra Barat. Jurnal Paedagogy, 8(3), 398-407. doi:https://doi.org/10.33394/jp.v8i3.3850

https://doi.org/10.33394/jp.v8i3.3850

This is an open-access article under the CC-BY-SA License.

\section{Pendahuluan}

Ilmu Pengetahuan Alam (IPA) adalah mata pelajaran yang dapat mengembangkan kemampuan berfikir secara kualitatif dan kuantitatif. Melalui pelajaran IPA siswa dapat mengembangkan pengetahuan, kecakapan, kreativitas siswa, meningkatkan motivasi, semangat yang kuat dan aktifitas siswa yang tinggi. Siswa diharapkan dapat menyenangi pelajaran IPA dan dapat memecahkan masalah baik sewaktu pembelajaran di kelas maupun 
pada kehidupan sehari-hari (Abdi Guru, 2014). Sehingga berdampak pada hasil akhir dari mata pelajaran IPA diperoleh nilai yang memuaskan.

Berdasarkan hasil pengamatan dan data pembelajaran di SMPN 7 Bukittinggi, hasil belajar siswa pada mata pelajaran IPA masih rendah. Hal ini dikarenakan kurangnya minat dan aktivitas siswa dalam proses pembelajaran IPA dan rendahnya nilai input siswa yang masuk dilihat dari Ujian Nasional di Sekolah Dasar. Menyikapi masalah dan tujuan pendidikan IPA tersebut, pendekatan pembelajaran yang seharusnya dikembangkan adalah berpusat pada siswa. Pendekatan pembelajaran haruslah melibatkan siswa secara aktif dalam proses pembelajaran. Melvin (2006) mengemukakan bahwa "yang dapat membuahkan hasil belajar yang berkelanjutan hanyalah kegiatan belajar aktif". Agar belajar menjadi aktif, siswa harus banyak terlibat dalam proses PBM. Konkritnya siswa perlu mendengar, memperhatikan, menyimak, mengajukan pertanyaan, menjawab dan menanggapi Disamping itu kurangnya guru menggunakan metode untuk meningkatkan aktifitas siswa dalam proses pembelajaran. Pembelajaran selama ini masih berpusat pada guru (teacher centered), sedangkan siswa hanya mendengar dan mencatat apa yang diterangkan guru kemudian mengerjakan tugas-tugas.

Guru menemukan kendala terutama materi yang sifatnya hafalan, kecendrungan siswa hanya menerima informasi, bukan menggali informasi. Siswa kurang bersemangat belajar dan tidak ada merespon pelajaran di berikan. Apalagi pembelajaran dilaksanankan pada jam-jam terakhir, siswa sudah lelah dan mata sudah mulai mengantuk. Maka siswa akan sulit untuk memperhatikan pelajaran dengan sepenuh hati.

Melalui bahasan di atas ada beberapa hal yang ditemukan dalam pembelajaran IPA yaitu; (1) Hasil belajar IPA rendah; (2) kurangnya aktifitas siswa baik fisik maupun mental dalam proses belajar mengajar; (3) Ketrampilan yang dimiliki seorang guru kurang tepat dalam memilih strategi dan metode belajar; dan (4) Kurangnya kolaborasi antara siswa dengan guru atau antara sesama siswa.

Untuk memecahkan masalah diatas, guru perlu memilih strategi yang tepat sewaktu proses pembelajaran berlangsung yaitu melalui model pembelajaran kooperatif tipe jigsaw. Model Jigsaw adalah model belajar diskusi kelompok dimana siswa terdiri atas 2 kelompok yaitu: (1) kelompok kecil beranggotakan 5-6 orang yang disebut juga kelompok asal; (2) Kelompok besar yaitu kelompok yang anggotanya dari anggota kelompok asal yang mendapat soal sama, di sebut juga kelompok ahli. Setiap anggota kelompok asal diberi soal yang berbeda sehingga masing-masing siswa bertanggung jawab dengan soal yang jawabannya diperolehnya dari kelompok besar untuk diinformasikan kembali pada temanteman pada kelompok kecil (Heryekti, 2021; Nashirotun, 2020; Fajuri, 2019;, Nirta, 2019, dan Asni, 2017).

Adapun penelitian ini bertujuan untuk meningkatkan aktivitas belajar siswa dalam pembelajaran IPA melalui model pembelajaran kooperatif tipe jigsaw di kelas VII-8 SMP Negeri 7 Bukittinggi.

\section{Metode Penelitian}

Metode penelitian ini adalah penelitian tindakan kelas (Class Action Research). Penelitian ini dilaksanakan dengan menggunakan model siklus yang dikembangkan oleh Kemmis dan Mc Taggart (1992) yang terdiri da ri komponen-komponen Perencanaan (Planning), Tindakan (Acting), Observasi (Observing) dan Refleksi (Reflecting). Penelitian dilaksanakan dalam dua siklus, setiap siklus terdiri dari 2 kali pertemuan (tatap muka). Pada setiap siklus dilakukan pengamatan aktivitas siswa yang dilakukan pada saat proses belajar 
mengajar (2 x 40 menit). Penelitian ini dilaksanakan di kelas VII-8 SMP N 7 Bukittinggi. Subjek dalam penelitian ini adalah siswa kelas VII-8, dengan jumlah siswa 28 orang, yang terdiri dari 12 orang Laki-laki dan 16 orang Perempuan.

Teknik pengumpulan data yang dipergunakan dalam penelitian ini adalah teknik komunikasi tidak langsung. Adapun alat yang digunakan dalam teknik komunikasi tidak langsung yaitu dengan menggunakan lembar observasi yang dilakukan untuk mengumpulkan data tentang aktivitas siswa, yang meliputi kelengkapan bahan bacaan siswa, kerja sama siswa dalam kelompok, mengerjakan soal dalam kelompok, mengeluarkan pendapat, menunjuk tangan untuk menjawab kuiz yang diajukan guru didalam peleksanaan model pembelajaran Jigsaw. Untuk menentukan persentase aktivitas siswa digunakan data yang dianalisis secara deskriptif dengan menggunakan teknik Persentase. Untuk melihat ketercapaian tujuan penelitian digunakan interval menurut Arikunto (2016) adalah

$$
\begin{aligned}
& 81 \%-100 \%=\text { baik sekali }(\mathrm{BS}) \\
& 50 \%-80 \%=\text { baik(B), } \\
& 41 \%-50 \%=\operatorname{cukup}(\mathrm{C}) \\
& 21 \%-40 \%=\operatorname{kurang}(\mathrm{K}) \\
& 0 \%-20 \%=\text { kurang sekali(KS). }
\end{aligned}
$$

Setelah pembelajaran diharapkan aktivitas siswa dalam belajar IPA dapat meningkatkan aktivitas belajarnya, hal ini dapat dilihat dari indikator aktivitas belajar siswa berkategori baik yaitu antara $50 \%$ s/d $80 \%$.

\section{Hasil Penelitian dan Pembahasan}

Penelitian ini merupakan penelitian yang telah dilaksanakan sesuai dengan rangkaian kegiatan yang di mulai dari rencana, tindakan, observasi dan refleksi yang dilakukan pada setiap siklus. Untuk mengumpulkan data yang dibutuhkan, peneliti dibantu alat penelitian yang berbentuk pedoman observasi dan format observasi.

\section{Pelaksanaan Penelitian Tindakan Kelas pada Siklus 1}

Pelaksanaan siklus pertama terdiri dari 2 kali pertemuan. Hal ini dengan kompetensi dasar Kalor dan perpindahannya. Pertemuan pada Siklus Pertama adalah bulan oktober 2016. Fokus penelitian ini adalah peningkatan aktivitas belajar siswa melalui model pembelajaran kooperatif tipe Jig saw. Bagian ini memaparkan tentang pelaksanan dan hasil penelitian. Pertemuan pertama siklus 1, dilaksanakan pada hari Senin, tanggal 24 Oktober 2016 jam ke4,5 dan 6, dengan materi pelajaran terdiri dari :

Kalor dan perubahan suhu benda

Pertemuan kedua siklus 1, dilaksanakan pada hari Selasa, tanggal 25 Oktober 2016 jam ke-1 dan 2, dengan materi pelajaran terdiri dari:

Kalor dan perubahan wujud benda

Pertemuan pertama siklus 2, dilaksanakan pada hari Senin, tanggal 31 Oktober 2016, jam ke-1,2 dan 3, dengan materi pelajaran terdiri dari :

Perpindahan kalor secara konduksi dan konveksi

Pertemuan kedua siklus 2, dilaksanakan pada hari Selasa, tanggal 1 November 2016 jam ke-1 dan 2, dengan materi pelajaran terdiri dari:

Perpindahan kalor secara radiasi.

\section{Pelaksanaan Siklus 1}

\section{Tahap Perencanaan}

Setelah selesai pembelajaran dan penilaian pada Suhu dan Perubahannya dengan model pembelajaran biasa yaitu demontrasi dan ceramah interatif. Maka pada siswa di 
informasikan model pembelajaran yang akan dilaksanakan yaitu model Jigsaw pada Kompetensi Dasar berikutnya yaitu Kalor dan Perpindahannya dan bentuk penilaian yang dilaksanakan. Penilaian berupa aktivitas siswa, tes proses isian singkat dan ujian harian dengan prosedur tertulis berbentuk objektif setelah selesai materi Kalor dan Perpindahannya. Adapun langkah-langkah pada tahap perencanaan ini adalah:

a) Mempersiapkan perangkat pembelajaran seperti Program Tahunan. Program Semester, Rencana Pelaksanaan pembelajaran ( RPP ) dan scenario pembelajaran.

b) Memilih dan menentukan buku sumber atau buku penunjang yang sesuai dengan materi pelajaran.

c) Mempersiapkan pembagian kelompok siswa yang heterogen.

d) Menyiapkan instrument penelitian seperti : daftar nama siswa dan lembaran observasi aktivitas.

\section{Tahap tindakan}

Langkah-langkah pelaksanaan tindakan adalah sebagai berikut

a) Berdoa dan guru mencek absensi siswa, kemudian mencek tepat duduk siswa sesuai dengan denah.

b) Guru menjelaskan model pembelajaran yang dilaksanakan dengan model Jigsaw.

c) Guru menyampaikan tujuan pembelajaran dan memberikan appersepsi terhadap materi pembalajaran terdahulu yang berkaitan dengan materi yang akan dipelajari. Selanjutnya guru memberikan motivasi pembelajaran yang akan di bahas.

d) Guru menyebutkan kelompok siswa yang anggotanya 5 orang.

e) Guru menyuruh siswa duduk pada kelompoknya masing-masing.

f) Guru menyajikan informasi pembelajaran melalui ceramah interatif didepan kelas, siswa memperhatikan.

g) Guru membagi bahan diskusi.

h) Siswa yang mendapat bahan diskusi yang sama berkumpul pada satu kelompok besar (ahli) untuk membahasnya.

i) Guru mengawasi, membimbing dan memberi bantuan jika diperlukan.

j) Setelah diskusi pada kelompok besar, siswa kembali pada kelompok asalnya masingmasing dan setiap siswa bertindak sebagai seorang ahli untuk menjelaskan pada temanteman sekelompoknya secara bergantian.

k) Kemudian dilakukan diskusi antar kelompok yang di pimpin guru.

1) Setelah itu diadakan diskusi umum untuk menarik kesimpulan dan guru memberikan penekanan konsep.

m) Guru melakukan tanya jawab secara lisan

n) Guru memberikan tes proses dan memberi tahu tugas membaca materi berikutnya.

\section{Tahap Observasi}

Pada tahap observasi dilakukan pemantauan dan pengamatan pada kelompok asal dan kelompok besar misalnya: kelengkapan bahan bacaan siswa, kerja sama siswa dalam kelompok, mengerjakan soal dalam kelompok, mengeluarkan pendapat dalam kelompok dan menunjuk tangan untuk menjawab kuiz yang diajukan guru.

Tabel 1. Indikator Aktivitas Siswa Pada Pertemuan Pertama Siklus 1

\begin{tabular}{|c|l|c|c|}
\hline No & \multicolumn{1}{|c|}{ Aktivitas } & Jumlah Siswa & \% \\
\hline 1. & Bawa buku sumber/bacaan & 14 & 50 \\
\hline 2. & Kerjasama dalam Kelompok & 12 & 42,9 \\
\hline 3. & $\begin{array}{l}\text { Mengeluarkan pendapat } \\
\text { pada kelomok besar }\end{array}$ & 9 & 32,1 \\
\hline
\end{tabular}




\begin{tabular}{|c|l|c|c|}
\hline 4. & $\begin{array}{l}\text { Mengerjakan soal dalam } \\
\text { kelompok }\end{array}$ & 8 & 28,6 \\
\hline 5. & $\begin{array}{l}\text { Menunjuk tangan dalam } \\
\text { menjawab kuiz }\end{array}$ & 4 & 14,3 \\
\hline
\end{tabular}

Dilihat dari tabel 1, aktivitas siswa pada pertemuan pertama siklus 1, menunjukkan bahwa siswa yang membawa buku sumber/bacaan 14 orang (50\%), kerjasama dalam kelompok 12 orang $(42,9 \%)$, mengeluarkan pendapat pada kelompok besar 9 orang $(32,1 \%)$, mengerjakan soal dalam kelompok 8 orang $(28,6 \%)$, dan menunjuk tangan dalam menjawab kuiz 4 orang $(14,3 \%)$

Tabel 2. Indikator Aktivitas Siswa Pada Pertemuan Kedua Siklus 1

\begin{tabular}{|c|l|c|c|}
\hline No & \multicolumn{1}{|c|}{ Aktivitas } & Jumlah Siswa & \% \\
\hline 1. & Bawa buku sumber/bacaan & 17 & 60,7 \\
\hline 2. & Kerjasama dalam Kelompok & 15 & 53,6 \\
\hline 3. & $\begin{array}{l}\text { Mengeluarkan pendapat } \\
\text { pada kelomok besar }\end{array}$ & 11 & 39,3 \\
\hline 4. & $\begin{array}{l}\text { Mengerjakan soal dalam } \\
\text { kelompok }\end{array}$ & 11 & 39,3 \\
\hline 5. & $\begin{array}{l}\text { Menunjuk tangan dalam } \\
\text { menjawab kuiz }\end{array}$ & 6 & 21,4 \\
\hline
\end{tabular}

Pada tabel 2 menunjukkan peningkatan keaktifan siswa pada pertemuan kedua siklus 1 . Keaktifan siswa dalam membawa buku sumber/bacaan mengalami kenaikan menjadi 17 orang $(60,7 \%)$, kerjasama dalam kelompok naik menjadi 15 orang $(53,6 \%)$, mengeluarkan pendapat pada kelompok besar naik menjadi 11 orang $(39,3 \%)$, mengerjakan soal dalam kelompok naik menjadi 11 orang $(39,3 \%)$, dan dalam hal menunjuk tangan dalam menjawab kuiz naik menjadi 6 orang $(21,4 \%)$

Tabel 3. Perbandingan Antara Pertemuan 1, dan 2 pada Siklus 1

\begin{tabular}{|c|l|c|c|c|c|c|c|}
\hline \multirow{2}{*}{ No } & \multicolumn{1}{|c|}{ Aktivitas } & \multicolumn{2}{c|}{ Pert 1 } & \multicolumn{2}{c|}{ Pert 2 } & \multicolumn{2}{c|}{ Rata-rata } \\
\cline { 2 - 8 } & $\begin{array}{c}\text { Jumlah } \\
\text { siswa }\end{array}$ & $\mathbf{\%}$ & $\begin{array}{c}\text { Jumlah } \\
\text { siswa }\end{array}$ & $\mathbf{\%}$ & $\begin{array}{c}\text { Jumlah } \\
\text { siswa }\end{array}$ & \% \\
\hline 1. & Bawa buku sumber/bacaan & 14 & 50 & $\mathbf{1 7}$ & 60,7 & 16 & 57,1 \\
\hline 2. & $\begin{array}{l}\text { Kerjasama dalam } \\
\text { Kelompok }\end{array}$ & 12 & 42,9 & 15 & 53,6 & 14 & 50 \\
\hline 3. & $\begin{array}{l}\text { Mengeluarkan pendapat } \\
\text { pada kelomok besar }\end{array}$ & 9 & 32,1 & 11 & 39,3 & 10 & 35,7 \\
\hline 4. & $\begin{array}{l}\text { Mengerjakan soal dalam } \\
\text { kelompok }\end{array}$ & 8 & 28,6 & 11 & 39,3 & 10 & 35,7 \\
\hline 5. & $\begin{array}{l}\text { Menunjuk tangan dalam } \\
\text { menjawab kuiz }\end{array}$ & 4 & 14,3 & 6 & 21,4 & 5 & 17,9 \\
\hline & Jumlah & 47 & 167,9 & 60 & 214,3 & 55 & 196,4 \\
\hline & Rata-rata aktivitas siswa & 9,4 & 33,6 & 12 & 42,9 & 11 & 39,3 \\
\hline
\end{tabular}

Secara umum hasil penelitian pada siklus 1 ini sudah memperlihatkan hasil yang menggembirakan, namun persentase keaktifan siswa belum mencapai 50\% s/d 80\% yaitu $39,3 \%$. Ini berarti penelitian ini belum begitu berhasil dan direncanakan dilanjutkan dengan siklus kedua. 


\section{Tahap Refleksi}

Berdasarkan pengamatan waktu observasi maka hal-hal yang perlu disampaikan pada siswa adalah:

a) Menyarankan pada siswa untuk melengkapi buku sumber bacaan.

b) Siswa yang belum aktif pada kerja kelompok di motivasi agar lebih dapat bekerja sama dalam kelompoknya.

c) Materi yang belum dipahami siswa di perjelas kembali.

d) Memberikan tes proses ke 1 .

e) Menginformasikan materi yang akan dibahas pada pertemuan berikutnya

Pada siklus pertama diperoleh nilai rata-rata dari aktivitas siswa 2 kali pertemuan adalah 39,3\%. Ini disebabkan siswa masih belum memahami model pembelajaran Jigsaw karena baru pertama kali dilakukan pada proses pembelajaran. Beberapa siswa tidak membawa buku referensi sebagai bahan bacaan untuk diskusi sehingga sewaktu diskusi kelompok siswa belum dapat atau tidak bisa mengemukakan pendapatnya Disamping itu siswa masih malu , ragu dan merasa takut atau kurang percaya diri untuk mengemukakan pendapatnya.

\section{Pelaksanaan Siklus 2}

\section{Tahap Perencanaan}

Seperti pada siklus pertama mempersiapkan perangkat pembelajaran, alat, bahan yang diperlukan sesuai materi pelajaran. Pada siklus pertama waktu observasi ditemukan beberapa kendala antara lain : waktu terbuang dalam pembagian kelompok, suasan menjadi ribut sewaktu mencari dan tempat kelompok maka pada siklus ke 2 diadakan perobahan sebagai berikut:

a) Membagi kelompok siswa langsung sesudah selesai proses pembelajaran atau menempelkan kelompok dikelas sehari sebelum proses pembelajaran dilaksanakan.

b) Membuat papan nomor diskusi untuk kelompok besar dan langsung meletakkan pada meja kelompok besar masing-masing.

\section{Tahap Tindakan}
a) Tindakan dilakukan sama dengan siklus pertama.
b) Siswa duduk pada kelompok barunya masing-masing
c) Pembelajaran dilaksanakan model Jigsaw
d) Guru menjelaskan tujuan pembelajaran. appersepsi dan motivasi.
e) Guru melakukan demonstrasi didepan kelas, siswa memperhatikan.
f) Siswa diberi lembaran soal untuk didiskusikan dan siswa yang mendapat bahan diskusi yang sama duduk pada kelompok besar.
g) Setelah didiskusikan pada kelompok besar siswa kembali pada kelompok asal untuk mengiformasikan hasil diskusinya di kelompok besar terhadap teman-teman di kelompok asal.
h) Diadakan diskusi kelas yang diawasi dan dibimbing guru.
i) Guru memberikan penekanan konsep
j) Guru melakukan tanya jawab secara lisan.
k) Guru memberikan tes proses.

\section{Tahap Observasi}

Sama halnya observasi pada siklus pertama yaitu mengamati siswa mencari kelompok besar, membawa buku sumber bacaan, mengeluarkan pendapat, kerja sama dalam kelompok, mencari soal dalam kelompok dan jumlah siswa untuk menjawab pertanyaan guru. Hasil pengamatan observasi siklus 2 sebagai berikut : 
Tabel 4. Indikator Aktivitas Siswa Pada Pertemuan Pertama Siklus 2

\begin{tabular}{|c|l|c|c|}
\hline No & \multicolumn{1}{|c|}{ Aktivitas } & Jumlah Siswa & \% \\
\hline 1. & Bawa buku sumber/bacaan & 23 & 82,1 \\
\hline 2. & Kerjasama dalam Kelompok & 22 & 78,6 \\
\hline 3. & $\begin{array}{l}\text { Mengerjakan soal dalam } \\
\text { kelompok }\end{array}$ & 16 & 57,1 \\
\hline 4. & $\begin{array}{l}\text { Mengeluarkan pendapat pada } \\
\text { kelomok besar }\end{array}$ & 16 & 57,1 \\
\hline 5. & $\begin{array}{l}\text { Menunjuk tangan dalam } \\
\text { menjawab kuiz }\end{array}$ & 10 & 35,7 \\
\hline
\end{tabular}

Dilihat dari tabel diatas, aktivitas siswa pada pertemuan pertama siklus 2, menunjukkan bahwa siswa yang membawa buku sumber/bacaan 23 orang $(82,1 \%)$, kerjasama dalam kelompok 22 orang $(78,6 \%)$, mengeluarkan pendapat pada kelompok besar 16 orang $(57,1 \%)$, mengerjakan soal dalam kelompok 16 orang $(57,1 \%)$, dan menunjuk tangan dalam menjawab kuiz 10 orang $(35,7 \%)$

Tabel 5. Indikator Aktivitas Siswa Pada Pertemuan Kedua Siklus 2

\begin{tabular}{|c|l|c|c|}
\hline No & \multicolumn{1}{|c|}{ Aktivitas } & Jumlah Siswa & \% \\
\hline 1. & Bawa buku sumber/bacaan & 24 & 85,7 \\
\hline 2. & Kerjasama dalam Kelompok & 25 & 89,3 \\
\hline 3. & $\begin{array}{l}\text { Mengeluarkan pendapat pada } \\
\text { kelomok besar }\end{array}$ & 20 & 71,4 \\
\hline 4. & $\begin{array}{l}\text { Mengerjakan soal dalam } \\
\text { kelompok }\end{array}$ & 17 & 60,7 \\
\hline 5. & $\begin{array}{l}\text { Menunjuk tangan dalam } \\
\text { menjawab kuiz }\end{array}$ & 12 & 42,9 \\
\hline
\end{tabular}

Sedangkan pada tabel diatas, menunjukkan keaktifan siswa pada pertemuan kedua siklus 2 dalam membawa buku sumber/bacaan 24 orang $(85,7 \%)$, kerjasama dalam kelompok 25 orang $(89,3 \%)$, mengeluarkan pendapat pada kelompok besar 20 orang $(71,4 \%)$, mengerjakan soal dalam kelompok 17 orang $(60,7 \%)$, dan menunjuk tangan dalam menjawab kuiz 12 orang $(42,9 \%)$.

Tabel 6. Perbandingan pertemuan 1, dan 2 pada sikllus 2

\begin{tabular}{|c|l|c|c|c|c|c|c|}
\hline No & \multicolumn{1}{|c|}{ Aktivitas } & \multicolumn{2}{c|}{ Pertemuan 1 } & \multicolumn{2}{c|}{ Pertemuan 2 } & \multicolumn{2}{c|}{ Rata-rata } \\
\cline { 2 - 7 } & $\begin{array}{c}\text { Jumlah } \\
\text { siswa }\end{array}$ & $\mathbf{\%}$ & $\begin{array}{c}\text { Jumlah } \\
\text { siswa }\end{array}$ & $\begin{array}{c}\text { Jumlah } \\
\text { siswa }\end{array}$ & \% \\
\hline 1. & Bawa buku sumber/bacaan & 23 & 82,1 & 24 & 85,7 & 24 & 85,7 \\
\hline 2. & $\begin{array}{l}\text { Kerjasama dalam } \\
\text { Kelompok }\end{array}$ & 16 & 57,1 & 20 & 71,4 & 18 & 64,3 \\
\hline 3. & $\begin{array}{l}\text { Mengeluarkan pendapat } \\
\text { pada kelomok besar }\end{array}$ & 16 & 57,1 & 17 & 60,7 & 17 & 60,7 \\
\hline 4. & $\begin{array}{l}\text { Mengerjakan soal dalam } \\
\text { kelompok }\end{array}$ & 10 & 35,7 & 12 & 42,9 & 11 & 39,3 \\
\hline 5. & $\begin{array}{l}\text { Menunjuk tangan dalam } \\
\text { menjawab kuiz }\end{array}$ & 87 & 310,6 & 98 & 350 & 94 & 335,7 \\
\hline & Jumlah & 17,4 & 62,1 & 19,6 & 70 & 18,8 & 67,1 \\
\hline & Rata-rata aktivitas siswa & & & & & & \\
\hline
\end{tabular}


Secara umum hasil penelitian pada siklus 2 ini sudah memperlihatkan hasil yang menggembirakan, dan persentase keaktifan siswa dalam bawa buku sumber/bacaan , kerjasama dalam kelompok sudah lebih $75 \%$. Walaupun di dalam aspek mengeluarkan pendapat pada kelompok besar, mengerjakan soal dalam kelompok, dan menunjuk tangan dalam menjawab kuiz masih kurang dari $75 \%$ tetapi sudah termasuk kategori baik yaitu antara $50 \%$ sd $80 \%$ dan secara umum presentase keaktivan siswa sudah 67,1\%. Ini berarti penelitian ini sudah berhasil dan peneliti menganggap tidak perlu dilanjutkan dengan siklus ketiga.

Tabel 7. Perbandingan Peningkatan Aktivitas Belajar Siswa Pada Siklus I dan Siklus II

\begin{tabular}{|c|c|c|c|c|}
\hline No. & Aktivitas Siswa & $\begin{array}{l}\text { Siklus I } \\
(\%)\end{array}$ & $\begin{array}{l}\text { Siklus II } \\
(\%)\end{array}$ & $\begin{array}{l}\text { Peningkatan } \\
(\%)\end{array}$ \\
\hline 1 & $\begin{array}{l}\text { Aktivitas siswa membawa buku } \\
\text { sumber/bacaan }\end{array}$ & 57,1 & 85,7 & 28,6 \\
\hline 2 & $\begin{array}{llll}\begin{array}{l}\text { Aktivitas } \\
\text { kelompok }\end{array} & \text { siswa } & \text { bekerjasama } & \text { dalam } \\
\end{array}$ & 50 & 85,7 & 35,7 \\
\hline 3 & $\begin{array}{l}\text { Aktivitas siswa mengeluarkan pendapat } \\
\text { pada kelompok besar }\end{array}$ & 35,7 & 64,3 & 28,6 \\
\hline 4 & $\begin{array}{l}\text { Aktivitas siswa mengerjakan soal dalam } \\
\text { kelompok }\end{array}$ & 35,7 & 60,7 & 25 \\
\hline 5 & $\begin{array}{l}\text { Aktivitas siswa menunjuk tangan dalam } \\
\text { menjawab kuiz }\end{array}$ & 17,9 & 39,3 & 21,4 \\
\hline & Jumlah & 196,4 & 335,7 & 139,3 \\
\hline & Rata-rata aktivitas siswa & 39,3 & 67,1 & 28 \\
\hline
\end{tabular}

\section{Tahap Refleksi}

a) Kepada siswa terus dimotivasi untuk membawa buku sumber bacaan, aktif dan bekerja sama dalam kelompoknya.

b) Membahas tentang hasil tes proses pada silkus 1

c) Memberikan tes proses

d) Selesai proses pembelajaran satu konsep IPA ( KD ) pada siswa diberi tahu pada pertemuan berikutnya akan diadakan Ulangan Harian.

Berdasarkan hasil pengamatan, penulis menemukan kelebihan dan kelemahan dalam penggunaan model pembelajaran Jigsaw, yaitu sebagai berikut

1) Kelebihan

Terbukti dari hasil observsi, model pembelajaran Jigsaw ini berhasil meningkatkan aktivitas siswa untuk membawa buku sumber/bacaan, bekerjasama dalam kelompok.

Selain aktif juga siswa menjadi senang, semangat, percaya diri dalam belajar.

2) Kelemahan

Secara kuantitas memang terjadi peningkatan aktivitas siswa namun dalam hal kualitas masih terdapat kelemahan yaitu waktu pergantian kelompok besar ke kelompok kecil ribut walaupun sudah di beri sangsi dengan nilai skapnya namun tetap juga ribut.

\section{Pembahasan}

Berdasarkan hasil observasi ternyata model pembelajaran Jigsaw sudah dapat meningkatkan aktivitas siswa. Karena siswa sudah memahami model pembelajaran Jigsaw. Beberapa siswa sudah membawa buku referensi untuk bahan bacaan, sudah berani untuk mengemukakan pendapat dalam diskusi dan bekerja sama dalam kelompok. Ini dapat dilihat adanya peningkatan pada rata-rata presentase aktivitasnya adalah $67,1 \%$. 
Sehingga berdasarkan hasil penelitian, dapat disimpulkan bahwa keaktifan siswa pada siklus 2 mengalami peningkatan dibandingkan dengan siklus 1 . Pada aspek membawa buku sumber/bacaan naik $28,6 \%$ dari $57,1 \%$ pada siklus 1 menjadi $85,7 \%$ pada siklus 2 . Pada aspek, kerjasama dalam kelompok naik $35,7 \%$ dari $50 \%$ pada siklus 1 menjadi $85,7 \%$ pada siklus 2, mengeluarkan pendapat pada kelompok naik 28,6\% dari 35,7\% pada siklus 1 menjadi $64,3 \%$ pada siklus 2, mengerjakan soal dalam kelompok naik $25 \%$, dari $35,7 \%$ pada siklus 1 menjadi $60,7 \%$ pada siklus 2 , dan menunjuk tangan dalam menjawab kuiz naik $21,4 \%$ dari $17,9 \%$ pada siklus 1 menjadi $39,3 \%$ pada siklus 2 . Ini berarti penelitian ini berhasil dan tidak perlu dilanjutkan dengan siklus berikutnya.

\section{Kesimpulan}

Berdasarkan hasil analisa aktivitas belajar serta pembahasan yang telah dikemukakan maka penulis menarikm kesimpulan sebagai berikut: (1) Proses pembelajaran dengan model pembelejaran Jigsaw dapat meningkatkan aktivitas dan hasil belajar IPA siswa. (2) Siswa memiliki kepercayaan diri untuk mengemukakan pendapat dalam diskusi dan bekerja sama dalam kelompok, menyelesaikan soal dalam kelompok dan berani menunjuk tangan untuk menjawab pertanyaan guru, karena dengan model pembelajaran Jigsaw ini masing-masing siswa bertanggung jawab memegang satu konsep materi untuk di kemukakan atau dijelaskan pada teman-temanya sekelompok asalnya.

\section{Saran}

Adapun saran yang dapat disampaikan bersarkan hasil penelitian ini antara lain adalah: (1) bagi guru mata pelajaran lain agar dapat mengadopsi penelitian ini dengan memodifikasi implementasinya, (2) Pembagian anggota kelompok hendaklah diacak supaya tidak menumpuk siswa yang sama pada kelompok besar sehingga tidak menimbulkan kebosanan. (3) Apabila pembagian kelompok untuk siklus berikutnya tidak bisa dilakukan sesudah proses pembelajaran maka hendaknya pembagian kelompok di lakukan sehari atau dua hari sebelum proses pembelajaran berikutnya dilaksanakan dengan cara menempelkan di lokal siswa tempat penelitian.

\section{Daftar Pustaka}

Abdi Guru. (2014). IPA Terpadu, Jilid 1 Kelas VII SMP. Jakarta: Penerbit Erlangga

Ali, Mohammad. (2004). Guru Dalam Proses Belajar Mengajar. Sinar Baru : Bandung.

Arikunto, Suharsimi. (2016). Penelitian Tindakan Kelas. Jakarta: Bumi Aksara Tim

Asni, H. (2017). Upaya Meningkatkan Aktivitas dan Hasil Belajar Peserta Didik Melalui Penerapan Pendekatan Cooperative Learning Tipe Jigsaw di Kelas III-A SD Negeri

2 Cakrangeara. Jurnal Kependidikan: Jurnal Hasil Penelitian dan Kajian Kepustakaan di Bidang Pendidikan, Pengajaran dan Pembelajaran, 3(2). doi:https://doi.org/10.33394/jk.v3i2.567

Dimyati. (2006). Strategi belajar mengajar. Depdikbud Dirjen Pendidikan Tinggi P2TK

Fajuri, F. (2019). Penerapan Pendekatan Cooperative Learning Tipe Jigsaw dalam Upaya Meningkatkan Aktivitas dan Hasil Belajar Peserta Didik Kelas I SD Negeri 27 Ampenan. Jurnal Paedagogy, 6(1), 20-26. doi:https://doi.org/10.33394/jp.v6i1.2526

Heryekti Pujingsih, R. (2021). Meningkatkan Motivasi dan Hasil Belajar Matematika dengan Metode Kooperatif Tipe Jigsaw di SMA Negeri 1 Gerung. Jurnal Paedagogy, 8(1), 50-56. doi:https://doi.org/10.33394/jp.v8i1.3196

Hamalik, Oemar. (2011). Metoda belajar dan Kesulitan Belajar. Tarsito : 
Bandung.

Hasibuan, J.J. (2008). Proses Belajar Mengajar. Bangun Raya : Bandung.

Ibrahim, Muslimin (2000). Pembelajaran Kooperatif. Unesa-University Press: Surabaya.

Kemmis S dan Mc.Taggart. (1992). The Action Research Planner. Victoria: Deakrin University.

Melvin. L. (2006). Active Learning: 101 Cara Belajar Siswa Aktif. Bandung: Nuansa.

Nashirotun, B. (2020). Peningkatan Aktivitas dan Hasil Belajar Siswa dengan Metode Jigsaw dan Media Tubuh Manusia pada Pembelajaran IPA di MTs. Negeri 4 Klaten Jawa Tengah. Jurnal Paedagogy, $\quad 7(4), \quad$ 402-407. doi:https://doi.org/10.33394/jp.v7i4.2945

Nirta, I. (2019). Upaya Meningkatkan Aktivitas dan Hasil Belajar Peserta Didik Kelas IV SD Negeri 14 Cakranegara Melalui Penerapan Pendekatan Cooperative Learning Tipe Jigsaw. Jurnal Paedagogy, 6(1), 8-13. doi:https://doi.org/10.33394/jp.v6i1.2524

PUSKURBUK. (2014). Ilmu Pengetahuan Alam SMP/MTS Kelas VII Semester 1.

Riyanto, Yatim. (2008). Paradigma baru Pembelajaran. Kencana. Surabaya

Roestiyah, NK. (1994). Masalah Pengajaran Sebagai Suatu Sistem. Rineka Cipta : Jakarta.

Slameto. (2003). Proses Belajar Mengajar Dalam Sistem Kredit Semester. Bumi Aksara ; Jakarta. 